J. Perinat. Med. 4 (1976) 106

\title{
The use of dextrostix and dextrostix reflectance meters in the diagnosis of neonatal hypoglycemia
}

\author{
D. R. Harvey, L. V. Cooper, R. F. Fancourt, M. Levene, T. Schoberg
}

\section{Introduction}

Since the introduction of Dextrostix in 1964 as a rapid screening method for blood glucose, it has been used extensively both for the management of diabetes and the detection of neonatal hypoglycemia. There has always been some anxiety about the accuracy of the strips in estimating very high or very low blood sugars [1]. There has also been anxiety about inter-observer variability and for this reason, AMES, in 1970, introduced a reflectance meter which measured the color of the strip electronically. This was shown to be inaccurate at high levels [3] and was superseded in 1973 by the Dextrostix-Eyetone meter.

The aim of this study was to assess the accuracy of the meter compared to a routine laboratory chemical method, and to see whether it provided a more reliable assessment of blood glucose than judging the color of the Dextrostix by eye.

The study was done in two parts. In the first, pilot study the original reflectance meter was used and because this was subsequently withdrawn from the market the Dextrostix-Eyetone meter was used for the second series.

\section{Methods}

\subsection{Series I. Pilot Study}

Blood samples were obtained from 46 babies. Dextrostix estimations were performed according to the manufacturers' instructions, readings were made by two independent observers and a reading was taken on the reflectance meter. The blood was
Curriculum vitae

David HARVEY was born in 1936. He did his undergraduate training at Guy's Hospital in London, qualifying in 1960. His paediatric training has been spent mainly in London at the Hammersmith Hospital and the Hospital for Sick Children, Great Ormond Street. He has worked for short periods in France and Australia. He worked in the Nuffield Institute for Medical Research in Cxford for one year. He is now Consultant Paediatrician at Queen Charlotte's Maternity Hospital and St. Charles' Hospital in London.

then deproteinized immediately to prevent further glycolysis and measured chemically by a glucose. oxidase method. The mean 'of the observers' readings was used in the subsequent calculations.

\subsection{Series II}

180 cord blood samples were collected, because we were primarily interested in low levels of blood glucose, they were allowed to stand at room temperature for several hours to allow glycolysis to occur. The study was performed in the same way as the pilot study except that the DextrostixEyetone meter was used.

\subsection{Results. Series I}

The meter showed a marked tendency to overestimate the blood glucose, 44/46 samples were 


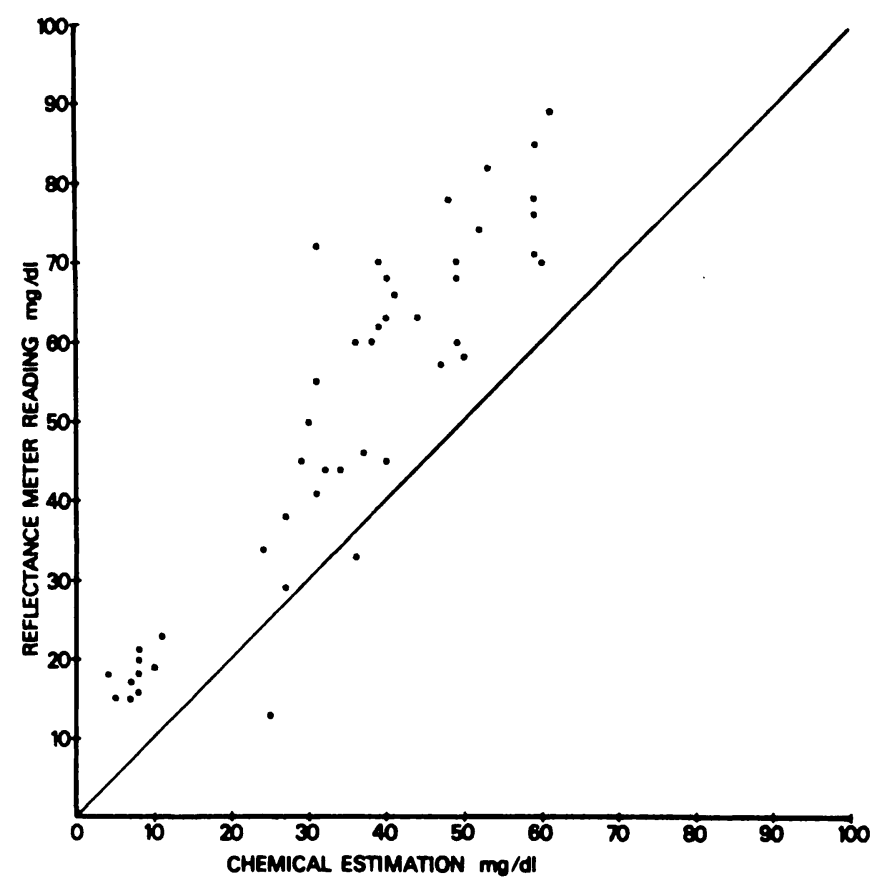

Fig. 1. Series I. Correlation between meter readings and chemical estimation of blood glucose.

over-estimated indicating a fault in the calibration of the meter (Fig. 1). Readings obtained by eye did not show the same tendency; 20/46 were overestimated, 26/46 were under-estimated (Fig. 2). On two samples both the observers and the meter estimated that the level was above $20 \mathrm{mg} / \mathrm{d} 1$, but the chemical method showed a blood sugar concentration below this value.

\subsection{Series II}

In this series there was a strong correlation between the true glucose value and the meter readings ( $r=0.8877, p=<0.00005$ ) with no tendency towards over-estimation (Fig. 3). A similar correlation was seen for the observers' reading with the chemical method $(r=0.8533, p=<0.00005)$, although there was a tendency to under-estimate the blood glucose (Fig. 4). 104 samples were under-estimated, 61 were over-estimated and 15 samples were exactly the same.

Because our main interest was in the detection of neonatal hypoglycemia, for which we took the conventional though not universally accepted figure of $20 \mathrm{mg} / \mathrm{dl}$, we then looked at the number of false negatives in each group; that is samples which were thought by Dextrostix to be above $20 \mathrm{mg} / \mathrm{dl}$ but

J. Perinat. Med. 4 (1976)

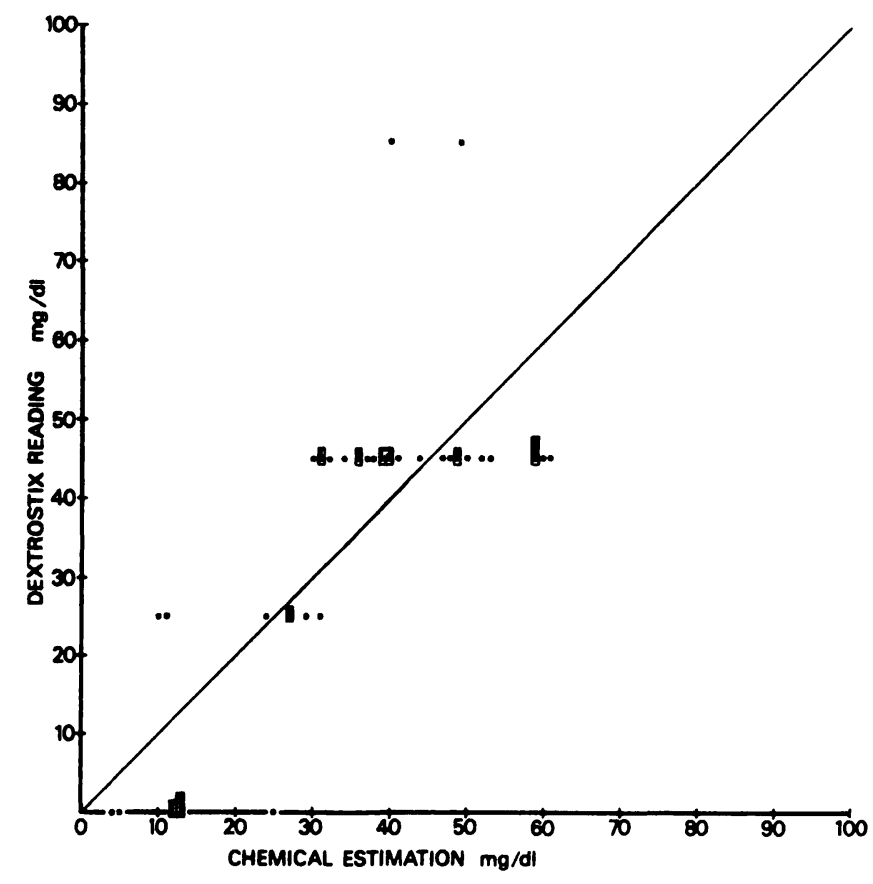

Fig. 2. Series I. Correlation between observers' Dextrostix readings and chemical estimation of blood glucose.

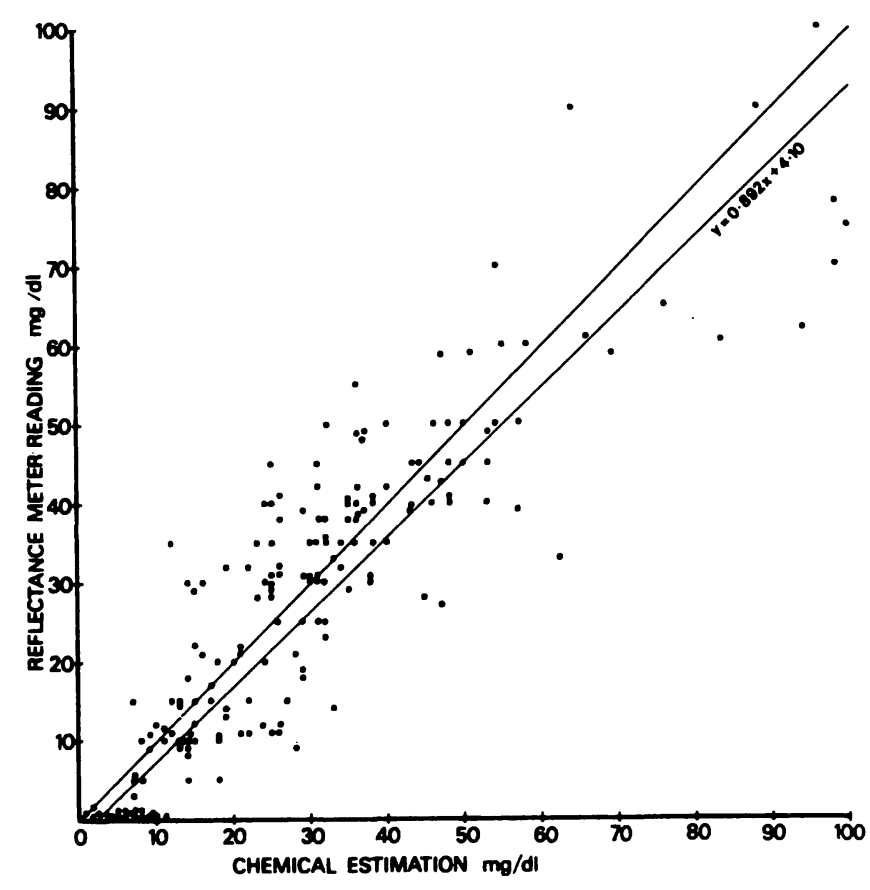

Fig. 3. Series II. Correlation between meter readings and chemical estimation of blood glucose.

which on chemical analysis proved to be lower. The meter readings gave rise to 7 false negatives, the observers 12 . However the difference between these is not statistically significant $\left(\chi^{2}=1.38\right.$; $0.3>\mathrm{p}>0.2$ ). 


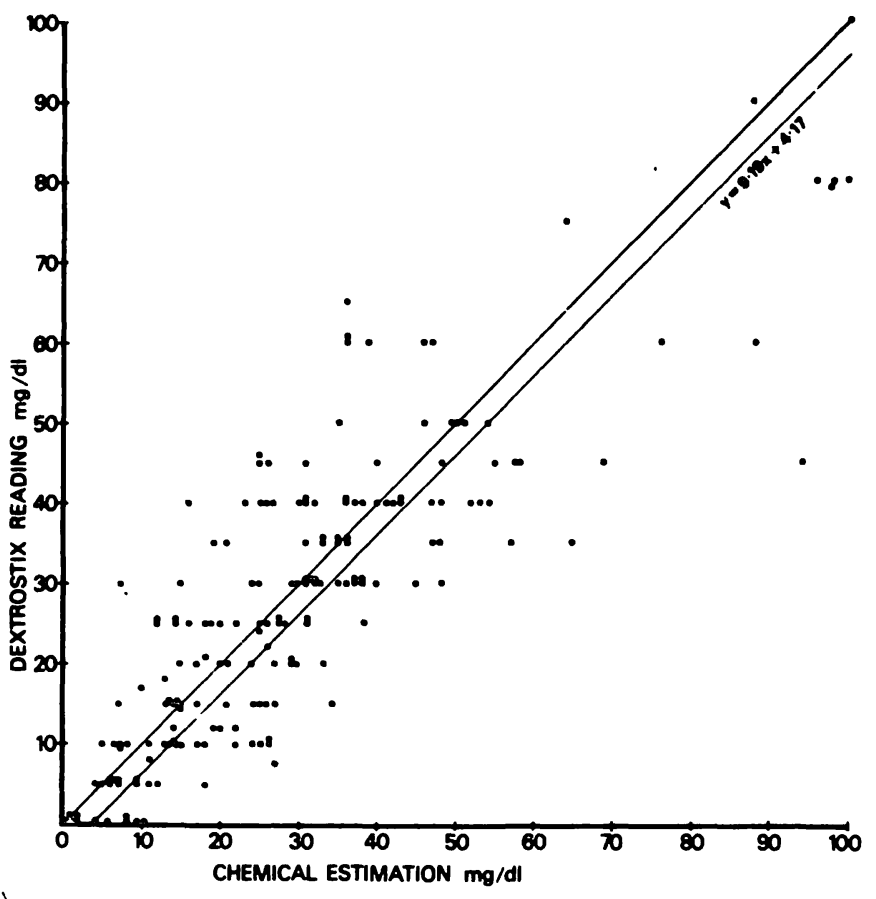

Fig. 4. Series II. Correlation between observers' Dextrostix readings and chemical estimation of blood glucose.

The discrepancy between the dextrostix readings and the true blood sugar was then investigated. In the meter group all of the 7 false negatives had blood glucose levels between 12 and $20 \mathrm{mg} / \mathrm{dl}$. Thus none of them fell into the profoundly hypoglycemic group of less than $10 \mathrm{mg} / \mathrm{dl}$. In the observers' group, 11 of the 12 false negatives were between 12 and $20 \mathrm{mg} / \mathrm{dl}$, but one sample was only $7 \mathrm{mg} / \mathrm{d} 1$. This was the most disturbing sample in the whole series since the observers had estimated the result as $30 \mathrm{mg} / \mathrm{dl}$ and the meter as $15 \mathrm{mg} / \mathrm{dl}$. In order to be certain that no sample had a blood glucose of less than $20 \mathrm{mg} / \mathrm{dl}$ it would have been necessary for the observers to be suspicious of any estimate below $40 \mathrm{mg} / \mathrm{dl}$ by eye or $35 \mathrm{mg} / \mathrm{dl}$ on the meter. This greatly reduces the usefulness of Dextrostix as a screening method for hypoglycemia. 82 and 49 samples in the two groups respectively would have been thought to be hypoglycemic.

\section{Summary}

Dextrostix is now widely used as a method of screening for hypoglycemia of the newborn. There has always been some anxiety about its accuracy for estimating very low blood sugars; this is important, since symptomatic hypoglycemia of the newborn does not usually occur until the blood glucose falls below $20 \mathrm{mg} / \mathrm{dl}$. In 1970 a reflectance

\section{Discussion}

It is obvious in our first series where all but two of the samples were over-estimated, that the calibration of the machine was inaccurate; this was shown also by JUNKER [3]. This weakness was recognised by the manufacturers who introduced the Eyetone Meter with a two point calibration. This new meter is mains-operated instead of using a battery and therefore can be expected to produce more reliable results over a period of time. The first series did not suggest that the meter was better than the eye at detecting blood sugars below $20 \mathrm{mg} / \mathrm{dl}$. The groups were too small for statistical analysis.

The second series showed a strong correlation between the meter readings and the glucose oxidase method. The calibration difficulty had been overcome. This has also been shown by the other studies $[4,5]$. Those two studies included very few samples with low blood sugars as they were interested in the use of the meter in diabetic clinics.

CHANTLER in 1967 [2] produced a very encouraging report on Dextrostix. They looked only at the ability of the strips to detect a glucose level below $20 \mathrm{mg} / \mathrm{dl}$. In a series of 380 blood samples they only had one $(0.26 \%)$ false negative. This compares with $3 \%$ for meter reading and $6.6 \%$ for observer readings in this article.

Although the meter gave a lower incidence of false negatives, the difference between the two was not statistically significant. It would seem therefore that the meter has little advantage over the dextrostix color-scale to be read by eye. There is also the danger that ward staff will be more inclined to believe a meter reading. whereas they may have a higher index of suspicion about a color which they have judged by eye.

It is possible to miss a low blood glucose by using Dextrostix; a chemical estimation should be obtained if a baby develops any suspicious symptoms.

meter was introduced which would measure the colour of the strip electronically. The aim of this study was to assess the accuracy of the meter and its reliability in estimating hypoglycemia. The study was continued to investigate a new model of the reflectance meter which superseded the original one. 
In the pilot study using the original model, blood samples were taken from 46 babies. Readings of the Dextrostix were made by two independent observers and compared with a reading taken on the reflectance meter. These estimations were later compared with blood glucose measured by the glucose oxidase method. The meter showed a marked tendency to overestimate the blood glucose: 44 out of 46 samples were overestimated (Fig. 1, 2).

In the second series 180 cord blood samples were collected. Because the intention was to study very low levels of blood glucose, the samples were allowed to stand at room temperature for several hours to allow glycolysis to occur. Again, readings were taken by two independent observers and compared with the readings taken on the new Dextrostix-Eyetone meter. The blood glucose was measured on each of the samples. There was a strong correlation $(r=0.8877, p<0.00005)$ between the blood glucose values and the readings taken from the meter, with no

Keywords: Dextrostix, glucose, hypoglycaemia, newborn.

\section{Zusammenfassung}

Über den Einsatz von Dextrostix-Stäbchen und eines Dextrostix-Reflektometers bei der Diagnostik der neonatalen Hypoglykämie.

Dextrostix-Stäbchen werden heutzutage in großem Stil als Screening-Methode für die Erkennung der neonatalen Hypoglykämie eingesetzt. Es hat schon immer Bedenken gegeben hinsichtlich der Genauigkeit von Dextrostix bei der Bestimmung von sehr tiefen Blutzuckerwerten. Dies ist insofern wichtig, als die symptomatische Hypoglykämie des Neugeborenen normalerweise erst Symptome macht, wenn der Blutglukosegehalt unter $20 \mathrm{mg} \%$ abgesunken ist. 1970 wurde ein Reflektometer eingeführt, der die Farbgebung des Stäbchens elektronisch bestimmte. Das Ziel dieser Studie bestand darin, die Genauigkeit des Reflektometers und seine Zuverlässigkeit hinsichtlich der Erkennung einer Hypoglykämie zu prüfen. Weiterhin sollte ein neues Reflektometer-Modell erprobt werden, das dem Original-Modell überlegen schien.

In einer ersten Studie wurde das Original-Modell verwendet und Blutproben von 46 Neugeborenen untersucht. Die Dextrostix-Bestimmungen wurden von zwei unabhängigen Beobachtern abgelesen und mit den Reflektometerwerten verglichen. Die so geschätzten Werte wurden später mit den durch die Glukose-Oxidase-Methode gemessenen Blutzuckerwerten verglichen. Der Reflektometer zeigte eine deutliche Tendenz zur Überschätzung des Blutglukosegehaltes: von 46 Blutproben waren $44 \mathrm{zu}$ hoch geschätzt worden (Fig. 1, 2).

In einer zweiten Serie wurden 180 Nabelschnurblutproben gesammelt. Da es in der Studie beabsichtigt war, besonders tiefe Blutzuckerspiegel zu untersuchen, wurden die Blut- tendency towards overestimation (Fig. 3). A similar correlation $(r=0.8533, p<0.00005)$ was seen for the obsevers' readings and the chemical method, although there was a tendency to underestimate blood glucose (Fig. 4). When the meter gave an estimate of more than $20 \mathrm{mg} / \mathrm{dl}$, in no case was the actual blood glucose in the profoundly hypoglycemic group of less than $10 \mathrm{mg} / \mathrm{dl}$. When estimated by eye there was one case in which the blood glucose was only $7 \mathrm{mg} / \mathrm{dl}$ but the observer had estimated the result of $30 \mathrm{mg} / \mathrm{dl}$. In order to avoid any possibility that a blood glucose was less than $20 \mathrm{mg} / \mathrm{dl}$, it is necessary to take action on any estimate below $40 \mathrm{mg} / \mathrm{dl}$ on a Dextrostix. Despite this, Dextrostix remains a very useful method of screening for neonatal hypoglycemia, whether assessed by eye or with the new DextrostixEyetone meter. The meter does give better results than estimating Dextrostix by eye, but the difference was never statistically significant. proben bei Zimmertemperatur für mehrere Stunden stehengelassen, wobei die Zellen weiter glykolysierten. Danach wurden wiederum von zwei unabhängigen Untersuchern die Werte bestimmt und mit jenen verglichen, die mit dem neuen Dextrostix-Eyetone-Meter gewonnen worden waren. In jeder Blutprobe wurde die Blutglukose bestimmt. Es fand sich eine gute Korrelation $(r=0.8877$, $\mathrm{p}<0.00005$ ) zwischen dem Blutglukosewert , s" und der Reflektometerablesung, die keine Tendenz zur Überbewertung zeigte (Fig. 3). Eine ähnliche Korrelation $(r=0.8533, p<0.00005)$ fand sich für die Werte, die durch die Ablesung eines Untersuchers und jene, die mit der chemischen Bestimmungsmethode gewonnen wurden, wenngleich hier eine Tendenz zur Unterbewertung des Blutglukosegehaltes nachgewiesen werden konnte (Fig. 4). Wenn beim Reflektometer ein Schätzwert von mehr als $20 \mathrm{mg} / \mathrm{dl}$ auftrat, fand sich in keinem einzigen Fall ein aktueller Blutglukosegehalt im tief hypoglykämischen Bereich von weniger als $10 \mathrm{mg} / \mathrm{dl}$. Wurde der Wert mit dem Auge geschätzt, so gab es einen Fall, bei welchem die Blutglukose nur $7 \mathrm{mg} / \mathrm{dl}$ betrug, während der Beobachter das Resultat auf $30 \mathrm{mg} / \mathrm{dl}$ geschätzt hatte. Um die Möglichkeit zu vermeiden, daß ein Blutglukosespiegel weniger als $20 \mathrm{mg} / \mathrm{dl}$ beträgt, ist es notwendig, bei jeder mit Dextrostix erfolgten Schätzung, die unterhalb $40 \mathrm{mg} / \mathrm{dl}$ liegt, aktiv zu werden. Unabhängig davon bleibt die DextrostixMethode eine sehr nützliche Suchmethodik für die neonatale Hypoglykämie, gleichgültig ob der Wert mit dem Auge abgelesen oder mit dem neuen Dextrostix-EyetoneMeter bestimmt wird. Der Reflektometer ergibt bessere Resultate als die Abschätzung mit dem Auge. Die Differenz war jedoch niemals statistisch signifikant.

Schlüsselwörter: Dextrostix, Glukose, Hypoglykämie, Neugeborenes.

Résumé

Utilisation de dextrostix et de mètres de reflétance dextrostix dans le diagnostic de l'hypoglycémie néonatale Le dextrostix est une méthode à présent largement diffusée pour examiner l'hypoglycémie des nouveaux-nés. On a toujours été inquiet quant à sa précision pour déceler les taux très bas de sucre sanguin, ce qui est important puisque l'hypoglycémie symptomatique du nouveau-né n'a lieu généralement que lorsque le glucose sanguin descend au- 
dessous de $20 \mathrm{mg} / \mathrm{dl}$ : En 1970, un mètre de reflétance a été introduit pour mesurer électroniquement la couleur du «strip». Le but de cette étude est de déterminer si le mètre est assez précis et sûr pour définir l'hypoglycémie. L'étude a été aussi poursuivie en vue d'établir un nouveau modèle de mètre de reflétance supervisant celui d'origine. Dans l'étude pilote utilisant le modèle d'origine, des spécimens sanguins avaient été prélevés sur 46 bébés. Les lectures du dextrostix ont été faites par deux observateurs indépendants, puis comparées avec un déchiffrage pris sur le mètre de reflétance. Ces estimations ont été confrontées par la suite avec du glucose sanguin évalué par la méthode d'oxydase de glucose. Le mètre a montré une tendance marquée à surévaluer le glucose sanguin: 44 sur 46 spécimens ont été surévalués (Fig. 1,2).

La deuxième série d'analyses portait sur 180 spécimens de sang ombilical. L'étude visant à analyser des taux très bas de glucose sanguin, les spécimens ont été laissés à la température ambiante pendant plusieurs heures pour faciliter la glycolyse. De nouveau, les déchiffrages ont

Mots-clés: Dextrostix, glucose, hypoglycémie, nouveau-né.

\section{Bibliography}

[1] COHEN, S. L., S. LEGG, R. BIRD: A bedside method of blood-glucose estimation. Lancet (1964) II, 883

[2] Chantler, C., J. D. BAUM, D. A. NORMAN: Dextrostix in the diagnosis of neonatal hypoglycaemia. Lancet (1967) II, 1395

[3] JUNKER, K., J. DITZEL: Inaccuracy of test strips with reflectance meter in determination of high blood sugars. Lancet (1972) I, 815 été faits par deux observateurs indépendants et comparés avec ceux effectués sur le nouveau Dextrostix-Eyetonemeter. Le glucose sanguin a été mesuré sur chacun de ces spécimens. On a observé une étroite corrélation ( $r=$ $0.8877 \mathrm{p}<0.00005)$ s'est montrée entre les lectures des observateurs et la méthode chimique, malgré une certaine tendance à sousévaluer le glucose sanguin (Fig. 4). Quand l'estimation était faite à vue, on enregistrait un seụl où le glucose sanguin était seulement de $7 \mathrm{mg} / \mathrm{dl}$ alors que l'observateur avait évalué le résultat à $30 \mathrm{mg} / \mathrm{dl}$. Afin d'empêcher qu'un glucose sanguin ne tombe au-dessous de $20 \mathrm{mg} / \mathrm{dl}$, il èst nécessaire d'intervenir dès l'observation d'une estimation inférieure à $40 \mathrm{mg} / \mathrm{dl}$ sur le dextrostix. En dépit de cela, le dextrostix reste une méthode très utile pour dépister une hypoglycémie néonatale que ce soit à vue ou par le Dextrostix Eyetọne-Meter. Le mètre donne des résultats quit sont meilleurs que l'estimation du dextrostix à vue, mais la difference était trop faible pour affecter les statistiques.

[4] SCHERSTER, B., C. KUHL, A. HOLLENDER, R. EKMAN: Blood glucose measurement with dextrostix and new reflectance meter. Brit. Med. Journal (1973) 3, 384

[5] WILlE, L., M. OBLADEN, S. APPELS: Blutzuckerbestimmung bei Neugeborenen mit Dextrostixreflektometer. Z. Kinderheilk. (1973) 293

Received May 7, 1975. Accepted November 17, 1975.

D. R. Harvey

Queen Charlotte's Maternity Hospital, Goldhawk Road, London W6 OXG United Kingdom. 